\title{
Polysaccharide-Based Edible Coatings Improve Eggplant Quality in Postharvest Storage
}

\author{
Leif Marvin R. Gonzales $^{1 \star}$ and Marilou M. Benitez ${ }^{2}$
}

\section{ABSTRACT}

Eggplant fruits are highly perishable as they have a short shelf life after harvesting. To prolong the shelf life of perishable goods, application of edible coatings has been utilized. Edible coatings have been used in various agricultural commodities to preserve their quality and prolong their postharvest life. This study was conducted to evaluate the effects of different polysaccharide-based edible coatings on the physico-chemical, biochemical, and physiological properties of eggplant fruits. The experiment was laid out in a Completely Randomized Design with nine (9) treatments and three (3) replications. Four (4) edible coatings were evaluated at two different concentrations. Sodium alginate $(A L)$, pectin $(P E)$, carboxymethyl cellulose (CMC), and cornstarch (CS) were tested at 1 and $2 \%$ concentrations. On days $0,3,6,9$, and 12 , samples were taken for the physicochemical, biochemical, and physiological analysis. The results of the study showed that the application of polysaccharide-based edible coatings significantly reduced weight loss and shriveling It also maintained firmness and VQR, prolonged shelf life, enhanced $\mathrm{pH}$, TSS, TA, preserved vitamin $\mathrm{C}$ content, maintained moisture and dry matter content, and reduced respiration and microbial count of eggplant without significantly affecting ethylene production. The different coatings (alginate, pectin, carboxymethyl cellulose, and cornstarch) significantly maintained the quality of eggplants for eight (8) days compared to the control. Among the different coatings tested, alginate showed the best result in maintaining the quality of eggplant fruit. It significantly reduced weight loss, shriveling, and microbial count, and preserved vitamin $\mathrm{C}$ content. Therefore, edible coatings, especially alginate, are effective in maintaining eggplant quality during postharvest storage.

Keywords: eggplant, polysaccharide, edible coating, starch, carboxymethyl cellulose, pectin, sodium alginate

\section{INTRODUCTION}

Fruits and vegetables are important in the human diet because of their health benefits to the body. But they are crops with a relatively short postharvest life because they remain as living tissues up until the time they are consumed. They are

\footnotetext{
${ }^{1}$ College of Agriculture and Fisheries, Capiz State University, Bailan, Pontevedra, Capiz, Philippines

${ }^{2}$ Department of Horticulture, Visayas State University, Baybay City, Leyte, Philippines 


\section{Polysaccharide-Based Edible Coatings Improve Eggplant Quality}

also susceptible to physiological and biochemical changes, which can have physical or pathological origins (Palou et al 2015), leading to important economic losses (Olivas and Barbosa-Cánovas 2009; Park 1999). Eggplant fruits are low in calories and are made of minerals that are beneficial to human health. They are very high in potassium. They are also a rich source of magnesium, calcium, and iron (Lawande and Chavan 1998; Kowalski et al 2003). Eggplant is a moderate respiration rate (RR) non-climacteric fruit $\left(30 \mathrm{~mL} \mathrm{CO} 2 \mathrm{~kg}^{-1} \mathrm{~h}^{-1}\right.$ at $12.5^{\circ} \mathrm{C}$, for fruit at intermediate stages of development) (Cantwell and Suslow, 2013). The fruit has two to three times higher RR and is therefore extremely perishable (Rodriguez et al 2001; Zaro et al 2014).

Postharvest treatments with conventional synthetic waxes and/or chemical fungicides have been used for many years to reduce postharvest decay and prolong fruit shelf life. However, the constant application of these treatments has resulted in health and environmental concerns, and the production of resistant pathogenic strains (Sapper and Chiralt 2018).

Thus, studies have looked into the use of edible coating, a thin layer of natural substances that cover the food product surface, to inhibit undesirable changes in flavor, texture, and appearance of the food product (Robertson 2006). Edible coatings with semi-permeable film prolong the postharvest life of fruits by decreasing moisture, respiration, gas exchange, and oxidative reaction rates (Petriccione et al 2015). Most coatings are formulated as liquid solutions to be applied on the surface of a crop for regulating moisture, solutes, and gaseous exchange between the internal and external atmosphere (Oms-Oliu et al 2010; Sánchez-González et al 2011).

There are several benefits of using polysaccharide-based coatings. They are low-cost, biodegradable, and water-soluble. Therefore, they do not require organic solvents before or during application (Debeaufort et al 1998). It has been shown that the application of edible polysaccharide-based coatings enriched with antimicrobials or antioxidants is effective in preserving the quality of the fruit during storage (Guerreiro et al 2016; Zhang et al 2015). In addition, polysaccharide has well-defined chemical structures that allow its coating characteristics to be modified. Due to their ability to form rigid and stable gels, edible coatings based on polysaccharides, such as alginate $(\mathrm{AL})$ and pectin $(\mathrm{PE})$, are mostly used (Campos et al 2011; Salmieri and Lacroix 2006).

Based on literature review, there are no studies on the effects of polysaccharidebased edible coatings and their different concentrations on the physico-chemical and physiological properties of eggplant fruits. Hence, this study was conducted to determine and evaluate the effect of different polysaccharide-based edible coatings on the physico-chemical and physiological properties of eggplant fruits and determine the best edible coating formulation in preserving the quality and in enhancing the shelf life of eggplant fruits.

\section{MATERIALS AND METHODS}

\section{Fruit Source}

Eggplants were grown by a contract grower in Brgy. Igang, Baybay City, Leyte. The eggplant fruits were harvested once they reached their commercial maturity 
stage and were immediately transported to the Postharvest Technology Laboratory of the Visayas State University, Visca, Baybay City, Leyte where these were selected for uniformity of size and freedom from defects for the experiments.

\section{Chemicals}

Food grade biopolymers, namely sodium alginate $(A L)$, carboxymethyl cellulose $(C M C)$, pectin $(P E)$, and cornstarch $(C S)$, were used for coating formulations. Calcium chloride was used to induce cross-linking reaction, ascorbic acid was added as an anti-browning agent, and glycerol as a plasticizer.

\section{Edible Coatings Preparation}

The coating-forming solutions were prepared by dissolving food grade sodium alginate, carboxymethyl cellulose, pectin, and starch powders into distilled water, gently stirring at $70^{\circ} \mathrm{C}$ until the solution became clear (Rojas-Graü et al 2008). The coating solutions were stored at $4^{\circ} \mathrm{C}$ until further use. Glycerol was added as a plasticizer at a concentration of $1.5 \mathrm{~mL} / 100 \mathrm{~mL}$ (Moreira et al 2015). Ascorbic acid at $1 \mathrm{~g} / 100 \mathrm{~mL}$ was added as an anti-browning agent (Robles-Sánchez et al 2009) and $\mathrm{CaCl} 2$ at $1 \mathrm{~g} / 100 \mathrm{~mL}$ was used as the final dip for cross-link (Robles-Sánchez et al 2013; Guerreiro et al 2015). Selected eggplant fruits were randomly distributed into nine (9) groups of 45 eggplant fruits each. One group was used as a control, in which samples were untreated, and the other four were treated with each of the coatings ( $A L, P E, C M C$, and $C S$ ). Four edible coatings at two different concentrations were evaluated. The treatments were: Control (fruit not coated or dipped in any treatment); AL 1\% (fruit coated with sodium alginate (10 g/L); AL 2\% (fruit coated with sodium alginate $(20 \mathrm{~g} / \mathrm{L}) ;$ PE $1 \%$ (fruit coated with pectin at 10 $\mathrm{g} / \mathrm{L}$ ); PE 2\% (fruit coated with pectin at $20 \mathrm{~g} / \mathrm{L}$ ); CMC 1\% (fruit coated with carboxymethyl cellulose at $10 \mathrm{~g} / \mathrm{L}$ ); CMC 2\% (fruit coated with carboxymethyl cellulose at $20 \mathrm{~g} / \mathrm{L}$ ); CS 1\% (fruit coated with cornstarch at $10 \mathrm{~g} / \mathrm{L}$ ) and CS $2 \%$ (fruit coated with cornstarch at $20 \mathrm{~g} / \mathrm{L}$ ). Coating the fruits involved two steps (Guerero et al., 2015): first, fruits were dipped into the edible coating solution + ascorbic acid + plasticizer for 2 minutes, then the excess of coating material was allowed to drip off for 30 seconds before the second dip in the calcium chloride solution for 1 minute. The temperature of the edible coating solution was adjusted to $25^{\circ} \mathrm{C}$ (Kaur et al., 2018). The amount of coating on the fruit was the difference between the initial weight of the edible coating solution and the weight recorded at draining time. Then, 15 fruits were placed in polypropylene plastic trays $(8 \mathrm{~cm} \times 10 \mathrm{~cm} \times 4 \mathrm{~cm})$ and stored at refrigerated temperature until analysis. The data gathering started on day 0 and continued at 3-day intervals. Relative humidity and temperature of the storage room were recorded daily until the termination of the study.

\section{Storage Condition}

The eggplant fruits were stored in an air-conditioned room with the temperature ranging from $8^{\circ} \mathrm{C}$ to $10^{\circ} \mathrm{C}$ and a relative humidity of $51 \%$ to $64 \%$. 


\section{Experimental Design and Treatment}

The study was laid out in Completely Randomized Design (CRD) with nine treatments (9) and three (3) replications. There were a total of 405 eggplant fruits with 45 fruits per treatment and 15 fruits per replications. The treatments were composed of different polysaccharide-based edible coatings at two concentrations and are as follows:

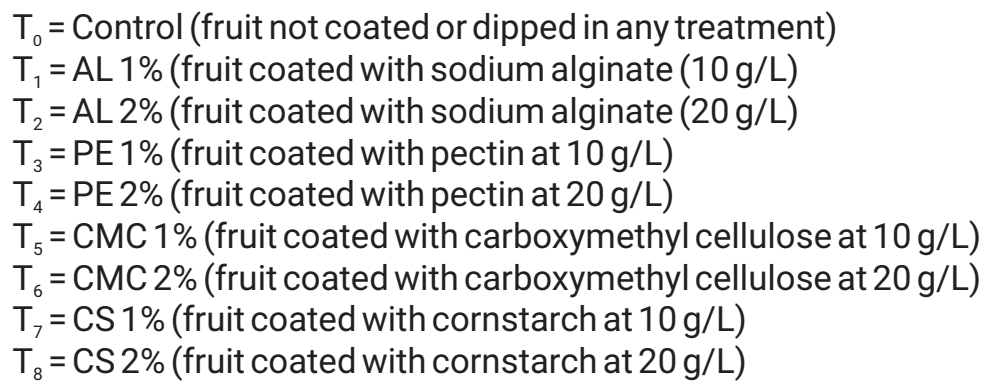

\section{Data Gathered}

Physico-chemical Properties

\section{Moisture Content (\%)}

Eggplant fruit moisture content was determined using six (6) sample fruits from each treatment. Sample fruits were weighed using a weighing scale before oven drying. Moisture content determination was done by drying the samples in an oven at $105^{\circ} \mathrm{C}$ for 16 hours until the weight became constant (ASTM D2974, 2007). Percent moisture content was measured as the weight loss during drying and expressed as a percentage of the wet sample. Percent moisture content was determined according to the following equation:

$$
\% \mathrm{MC}=\frac{\mathrm{FW}-\mathrm{DW}}{\mathrm{FW}} \times 100
$$

where $\mathrm{MC}$ is the eggplant moisture content, $\mathrm{Fw}$ is the fresh weight, and Dw is the dried weight.

\section{Dry Matter Content (\%)}

Eggplant fruit dry matter content was determined using three (3) sample fruits from each treatment. The sample fruit was weighed using a weighing scale before oven drying. The samples were then oven-dried at $105^{\circ} \mathrm{C}$ for 16 hours until weight became constant. These were then re-weighed (ASTM D2974, 2007). Percent dry matter content was measured as the remaining weight of the sample after drying and was expressed as a percentage of the wet sample. This was determined using 
the following formula:

$$
\% \mathrm{DMC}=\frac{\mathrm{Dw}}{\mathrm{Fw}} \times 100
$$

where DMC stands for dry matter content, Dw for dried weight, and Fw for the fresh weight of the sample fruit.

\section{Weight Loss(\%)}

To evaluate weight loss, five (5) separate samples in three (3) replicates of each treatment were used. The same samples were evaluated for weight loss at three (3) days interval until the end of the experiment. Weight loss was determined by the following formula:

$$
\text { Weight loss }(\%)=[(\mathrm{A}-\mathrm{B}) / \mathrm{A}] \times 100
$$

where $A$ indicates the fruit weight at the time of harvest and $B$ indicates the fruit weight at each sampling period (Akhtar 2010).

\section{Firmness ( $\mathrm{kg} /$ force)}

Fruit firmness was recorded with the use of a hand-held penetrometer. For this purpose, sample fruits from each replication were taken and the penetration force was measured by gently inserting the probe into the equatorial region of the fruit. The readings from each sample fruit were averaged to represent the corresponding treatments and the value was expressed in $\mathrm{kg} /$ force.

\section{Shriveling}

This was determined through the use of the shrivelingindex (SI) (Acedo 1999).

\begin{tabular}{cl} 
Shriveling Index & \multicolumn{1}{c}{ Description } \\
\hline 1 & No symptom of wilting/shriveling \\
2 & $1-10 \%$ surface wilting/shriveling \\
3 & $11-30 \%$ surface wilting/shriveling \\
4 & $31-50 \%$ surface wilting/shriveling \\
5 & Extensive wilting/shriveling \\
\hline
\end{tabular}

\section{Visual Quality Rating and Shelf life}

The visual quality of the samples was evaluated using the visual quality rating (VQR) (Acedo 1999). The number of days to reach VQR 5 was taken as the potential postharvest life of the eggplant fruits stored at storage room condition. 
Polysaccharide-Based Edible Coatings Improve Eggplant Quality

\begin{tabular}{cl}
\hline VQR & \multicolumn{1}{c}{ Description } \\
\hline 9 & Excellent, field fresh or no defect \\
7 & Good, defects minor \\
5 & Fair, defects moderate, limit of marketability \\
3 & Poor, defects serious, limit of edibility \\
1 & Non -edibleunder the usual condition \\
\hline
\end{tabular}

$\mathrm{pH}$

Eggplant fruits from each treatment were cut into small slices and pooled. Samples were homogenized in a blender and portions of the homogenate were taken to determine the quality. The $\mathrm{pH}$ value of fruit was measured with a $\mathrm{pH}$ meter.

Total Soluble Solid ( ${ }^{\circ}$ Brix)

TSS in Brix\% was measured by a hand refractometer standardized with distilled water by placing 1-3 drops of juice on the prism of the instrument to take the reading.

\section{Titratable Acidity(\%)}

A $5 \mathrm{~mL}$ juice extract (aliquot) was measured and put into an Erlenmeyer flask or beaker and added with two (2) drops of 1\% phenolphthalein indicator. This was titrated with $0.1 \% \mathrm{NaOH}$ until the faint pink color and the volume of $\mathrm{NaOH}$ was recorded. TA was calculated as follows (Acedo 1999):

$$
\% \text { TA of predominant acid }=\frac{\mathrm{V} \times \mathrm{N} \times \mathrm{M}}{\mathrm{W}} \times 100
$$

where: $\quad \mathrm{V}$ - Volume of $\mathrm{NaOH}$ added, $\mathrm{ml}$

$\mathrm{N}$ - Concentration of $\mathrm{NaOH}$, normality $(\mathrm{N})$

$\mathrm{M}$ - Milliequivalent weight of predominant acid, $\mathrm{g} / \mathrm{meq}$ (citric acid- 0.064 and malic acid-0.067)

W - Weight equivalent of aliquot, $g$

$$
\mathrm{W}=\frac{\text { Weight of sample, } \mathrm{g}}{\text { Weight of sample }+ \text { volume of water added }} \mathrm{x \text {vol.ofthealiquot }}
$$

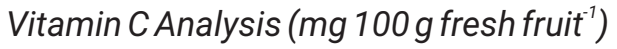

This was analyzed using the iodimetric titration method with the volumetry technique as described by Acabal et al (2015). 


\section{Physiological Properties}

\section{Respiration Rate}

This was measured by using a DansensorCheck Point $3 \mathrm{CO}_{2}, / \mathrm{O}_{2}$ Portable Headspace Gas Analyzer at the Postharvest Technology Laboratory, Department of Horticulture, Visayas State University. After allowing eggplant fruits to respire for one hour, the rubber tubing from the $\mathrm{CO}_{2}$ and $\mathrm{O}_{2}$ analyzer was inserted into the glass tubing of the respiration jars and the $\mathrm{CO}_{2}$ and $\mathrm{O}_{2}$ reading was recorded. Respiration rate was calculated as follows:

$$
\begin{aligned}
& \text { Respiration rate }\left(\mathrm{mg} \mathrm{CO} \cdot \mathrm{kg}^{-1} \mathrm{~h}^{-1}\right)=\text { net }(\%) \mathrm{CO}_{2} \times \frac{V}{\mathrm{~W}}(\mathrm{~T}) \\
& \text { where: } \mathrm{Net}(\%) \mathrm{CO}_{2}=\text { final }(\%) \mathrm{CO}_{2} \text { reading }-0.03 \% \mathrm{Co}_{2} \\
& \qquad \begin{aligned}
\mathrm{V} & =\text { Volume of free space, } \mathrm{mL} \\
\mathrm{W} & =\text { Weight of sample, } \mathrm{kg} \\
\mathrm{T} & =\text { Time of sealing in respiration jar, } \mathrm{h}
\end{aligned}
\end{aligned}
$$

\section{Ethylene Production}

This was measured using GC-2014 Shimadzu gas chromatograph for ethylene analyzer at the Harvested Products Regulation Laboratory, Philippine Root Crops Research and Training Center (PRCRTC). After allowing the eggplant fruits to respire for one hour, the rubber tubing was injected using a syringe and it was inserted into the gas chromatograph to get the ethylene vapor for analysis. Ethylene was calculated as follows:

$$
\begin{aligned}
& \mathrm{C}_{2} \mathrm{H}_{4}(\mathrm{~mL} / \mathrm{g} / \mathrm{hr})=\frac{\mathrm{R} 1}{\mathrm{R} 2} \times \frac{\text { VF }}{\mathrm{C} 2} \times \frac{(\mathrm{T}) \times(\mathrm{W})}{} \\
& \text { where: } \quad \mathrm{R} 1 \text { - ethylene reading for sample } \\
& \text { R2 - ethylene reading for standard } \\
& \text { C - Concentration of standard, } \mathrm{ppm} \\
& \text { VF-volume of headspace, } \mathrm{ml}=\text {, } \\
& \mathrm{ml}=\text { vol. of respiration jar-vol. of commodity } \\
& T \text { - Time interval, hour } \\
& \text { W- weight of the commodity, g }
\end{aligned}
$$

\section{Microbial Analysis}

Samples were submitted to the Microbiology Laboratory of the College of Veterinary Medicine, Visayas State University, Visca, Baybay City, Leyte for analysis of the microbial load. Experiments were done in triplicate. Results were expressed as Log10 CFU (Colony Forming Unit) per gram of fresh weight. 


\section{Polysaccharide-Based Edible Coatings Improve Eggplant Quality}

Statistical Analysis

Statistical analysis was carried out using Statistical Tool for Agricultural Research (STAR) software. One-way ANOVA and Tukey's honest significance test (Tukey's HSD test) for comparisons among treatments were performed.

\section{RESULTS AND DISCUSSION}

\section{Physico-chemical Properties}

\section{Moisture Content and Dry Matter Content}

The moisture and dry matter content of eggplant fruit as affected by the different coatings are presented in Figure 1. The Analysis of Variance showed that the result was significant $(p<0.01)$. It was noted that the highest moisture content was observed in fruits coated with alginate $(1 \%)$ while those coated with alginate (2\%) and pectin (1\%) had the lowest moisture content. The high moisture content of fruit coated with alginate (1\%) and cornstarch (2\%) was due to moisture barrier properties of the alginate as edible coating.

The dry matter content of eggplant was inversely proportional to its moisture content. The low dry matter content was caused by the high respiration rate of the eggplant fruit and the other way around. Olivas et al (2003) reported that edible coating acts as a barrier preventing water loss and causing high relative humidity in the microclimate surrounding the fruit surface leading to reduced moisture gradient in the outer part of the fruits.

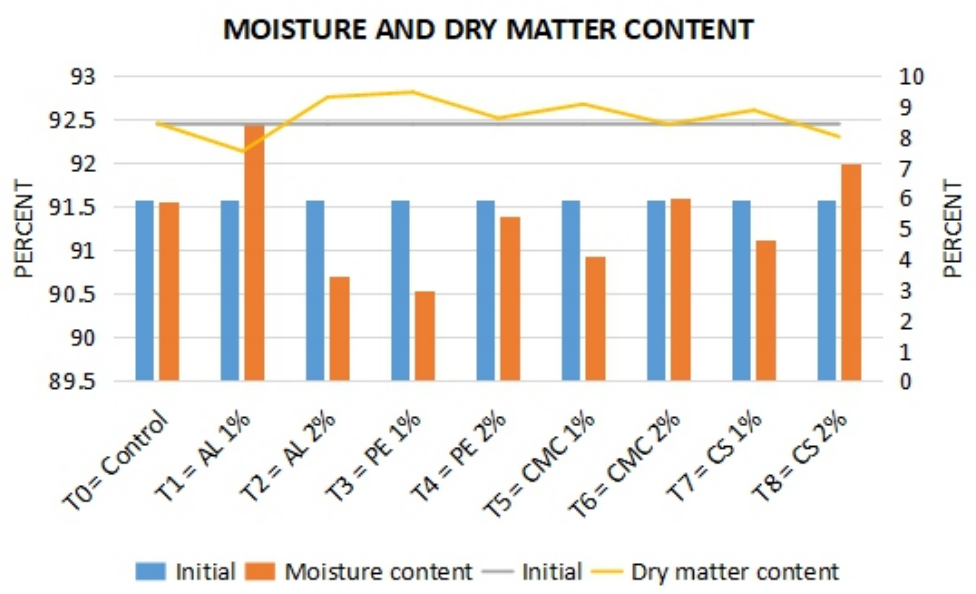

Figure 1. Moisture and dry matter content of eggplant fruits var. 'Morena' as influenced by alginate, pectin, carboxylmethyl cellulose, and cornstarch at 1 to $2 \%$ concentrations after 12 days of storage. 
Polysaccharide-based edible coatings significantly reduced the weight loss of eggplant fruits (Figure 2). The weight loss increased as the storage period increased until 12 days. All the fruits coated with polysaccharide-based edible coatings exhibited lesser weight loss compared to the control. The lowest weight loss among fruits that were treated was observed in those coated with alginate ( $1 \%$ and $2 \%$ ). Both concentrations of alginate resulted to the lowest respiration rate of coated fruits. Weight loss in fresh produce is mainly caused by the loss of water caused by transpiration and respiration (Zhu et al 2008). The percent weight loss increases throughout the storage period. Normally, the weight loss that occurs during fruit storage is due to its respiratory process and the transference of humidity and some processes of oxidation (Ayranci and Tunc 2003).

The lesser weight loss in fruits coated with different treatments as compared to the control is supported by the statement of Debeaufort et al (1998), that edible coatings are selective barriers to oxygen and carbon monoxide, modifying internal atmospheres and slowing down the respiration rate of fruit, which in turn reduces weight loss. The edible coating reduces transpiration and respiration by forming a semi-permeable layer (Dong et al 2004) that can be used as a protective barrier.

Moreover, differences in the ability to reduce weight loss are attributed to the different water vapor permeability of the polysaccharide used in the formulation of the edible coating (Vargas et al 2008). Edible coatings form a layer on fruit skin that controls water loss, defends fruit skin from mechanical damage and microbial attack, and seals small wounds (Nasrin et al 2017).

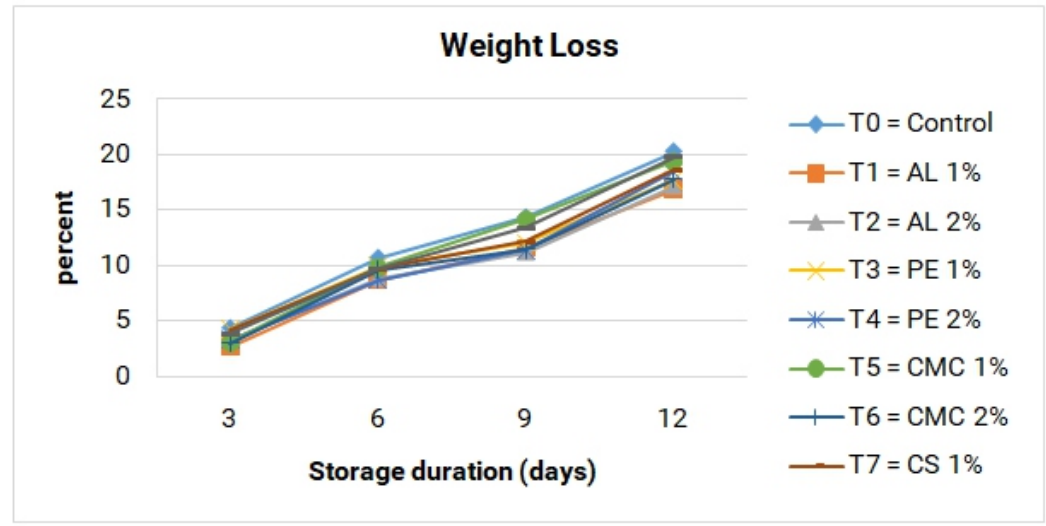

Figure 2. Weight loss of eggplant fruits var. 'Morena' as influenced by alginate, pectin, carboxylmethyl cellulose, and cornstarch at 1 to $2 \%$ concentrations after 12 days of storage.

\section{Firmness}

Texture is a major factor defining the quality of fruit and strongly influences consumer acceptability (Gonzalez-Aguilar et al 2008). During the ripening process of eggplants, cell walls facilitate the activity of various enzymes, including polygalacturonase. This causes the entire fruit to soften due to the decomposition 


\section{Polysaccharide-Based Edible Coatings Improve Eggplant Quality}

of the structural components needed to strengthen the cell layer and cell bonding (Amanullah et al 2016).

Fruit firmness was significantly affected by the application of different coatings. A gradual reduction of fruit firmness was observed from day 1 up to 12 days. HSD test shows that eggplant from the control treatment had the lowest mean which indicates the highest level of softening. It can be observed in Figure 3 that only a few treatments were comparable to the control during days 3,6 , and 9 of storage. However, after 12 days, all other coatings were already comparable to the control except for the $1 \%$ alginate. The retention of firmness in fruits coated with $1 \%$ alginate was due to the low respiration rate and ethylene production as noted in this study.

According to Valero et al (2013) and Valero and Serrano (2010), alteration in cell wall composition, particularly cell wall mechanical strength and cell-to-cell adhesion, are the most crucial factors contributing to the loss of firmness during fruit on-tree ripening or after harvesting. This is caused by the activity of cell wall hydrolyzing enzymes which increases the ethylene in climacteric fruit.

The $1 \%$ alginate coating was primarily effective in preventing or delaying the softening of fruits and vegetables compared to the control environment (Keneko et al 2002). Edible coatings decrease the water vapor transmission rate by forming a barrier around their substrates. This prevents texture reduction, as water is essential for the preservation of cell turgor (Perez-Gago et al 2010).

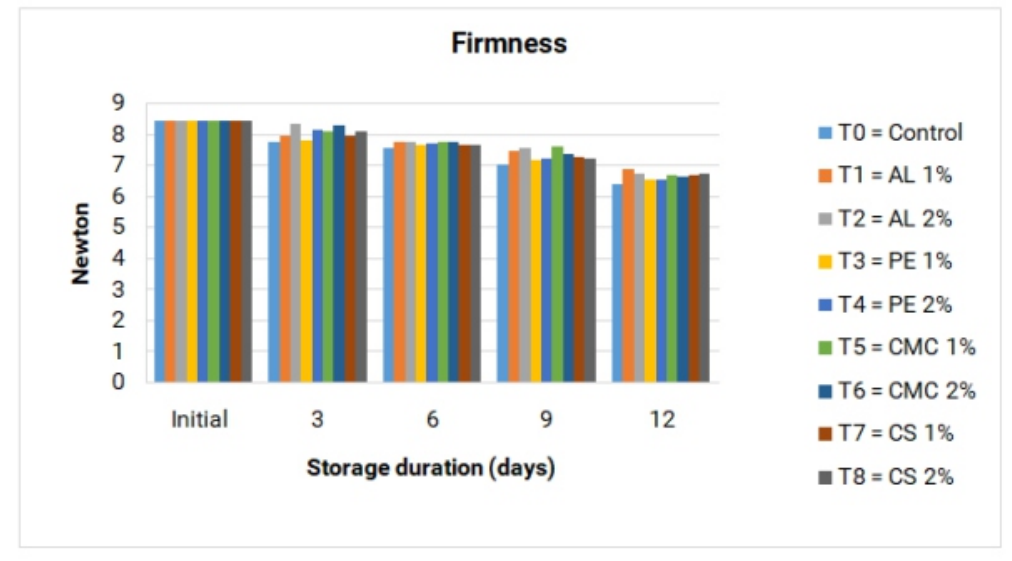

Figure 3. Firmness of eggplant fruits var. 'Morena' as influenced alginate, pectin, carboxylmethyl cellulose, and cornstarch at 1 to $2 \%$ concentrations after 12 days of storage.

\section{Shriveling}

Data on the degree of shriveling is presented in Figure 4. The degree of shriveling increased slowly during the storage period. The lesser the value of shriveling among the fruits from varying treatments, the better. The Analysis of Variance revealed significant differences among treatment means from day 3 until day 12.

Least significant difference test shows that the highest degree of shriveling 
was observed in the control but this was statistically comparable to some coatings except the fruits coated with alginate (1\%). Moreover, during the final day of data collection, fruits coated with alginate and cornstarch, both at $1 \%$ and $2 \%$, were comparably less shriveled compared to the control. Edible coating slow down the degree of shriveling of eggplant fruits, likely due to the effect of alginate and cornstarch, which act as a barrier for $\mathrm{O}^{2}$, altering the metabolic activity, and therefore the ripening process (Nazoori et al 2020).

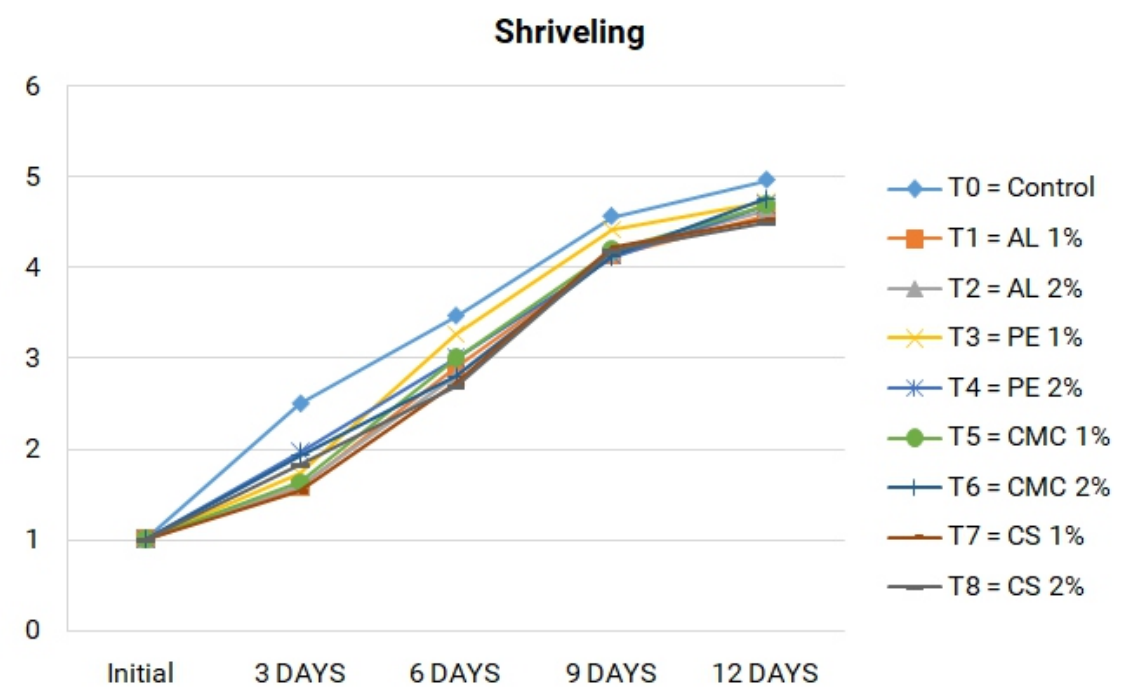

Figure 4. Shriveling of eggplant fruits var. 'Morena' as influenced by different polysaccharide-based edible coatings from day 3 to day 12 .

\section{Visual Quality Rating and Shelf Life}

The visual quality rating of eggplant as affected by the different coatings is presented in Figure 5. The VQR of eggplant was significantly affected by the different coatings used. The least VQR was noted in the control during the whole period of storage but this was comparable to other fruits with pectin, CMC, and cornstarch coatings after 12 days of storage. The best treatment in terms of VQR is $2 \%$ Alginate from day 3 to 12 . This was significantly higher than the control, though it was comparable to other coatings.

In terms of shelf life, the best treatments were alginate and cornstarch at $2 \%$ which preserved fruits for up to 10 days. This is higher compared to other coatings, however, the shelf life of other coated fruits was statistically comparable but not similar to the control. The positive effect of edible coating on storage life could probably be due to the effect of coatings in modifying the atmosphere. The modified atmosphere created could, therefore, delay the ripening by reducing respiration rate and the level of internal oxygen, and delaying ethylene production, consequently prolonging the storage life of fruit (Gol and Rao 2011).

Ben-Yehoshua (1985) reported that coating extends the shelf life of harvested commodities by decreasing $\mathrm{O}_{2}$ and increasing $\mathrm{CO}_{2}$ concentration, which reduces 


\section{Polysaccharide-Based Edible Coatings Improve Eggplant Quality}

the enzymatic activities responsible for quality deterioration. Moreover, Kittur et al. (2001) reported that polysaccharide-based coating formulations slowed down the metabolism to give prolonged storage life. They also reported an extension in the shelf life of banana by 21 days and of mangoes by 8 days relative to control fruits.

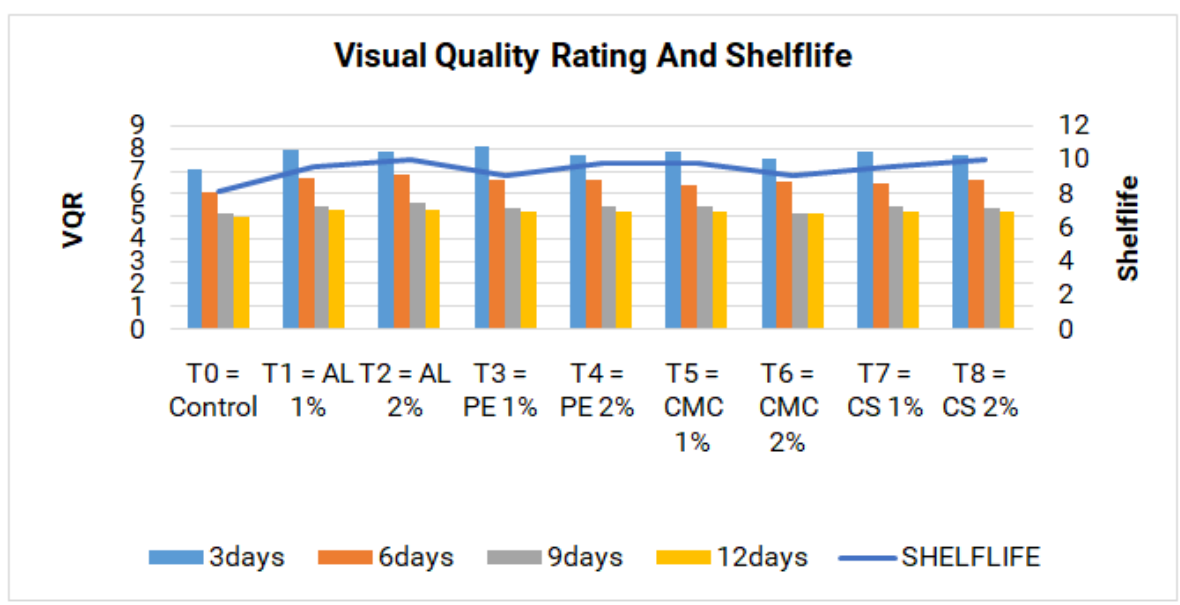

Figure 5. Visual quality rating and shelf life (day) of eggplant var. 'Morena' fruits as influenced by different polysaccharide-based edible coatings from day 3 to day 12 .

pH

The $\mathrm{pH}$ of fruits decreased numerically in all treatments during storage, which means that as the storage time increased, the fruits became more acidic (Figure 6). The Analysis of Variance showed that the results were significant at $(p<0.05) 3$ days until 12 days of storage. Honest significant difference test among treatments further shows that there was no constant pattern of effect in 3 days until 12 days of storage. More likely, all treatments were comparable with each other. The most observable difference was in fruits coated with pectin, the $\mathrm{pH}$ of which significantly increased compared to other treatments. However, this was statistically comparable to the control, alginate $(2 \%)$, and CMC (1\%) on the $12^{\text {th }}$ day of storage. The increase in $\mathrm{pH}$, particularly in fruit treated with pectin, might be connected to the utilization of organic acids by the respiration process during the storage (Nazoori et al 2020). Natalia (2012) and Menezes and Athmaselvi (2016) noted that as the storage time passes, senescence occurs in fruits during which there will be increase in the $\mathrm{pH}$ value.

It is reported that, during ripening, organic acids are used as substrates in respiration metabolism; thus, TA would decrease and $\mathrm{pH}$ and TSS would increase (Radi et al 2017). Since organic acids such as malic or citric acid are the primary substrates for respiration, a reduction in acidity and an increase in $\mathrm{pH}$ are expected in highly respiring fruit (Yaman and Bayoindirli 2002). Moreover, the linear increase in $\mathrm{pH}$ might be ascribed to biochemical, structural, and physiological alterations taking place during respiration (Ullah et al 2017). 


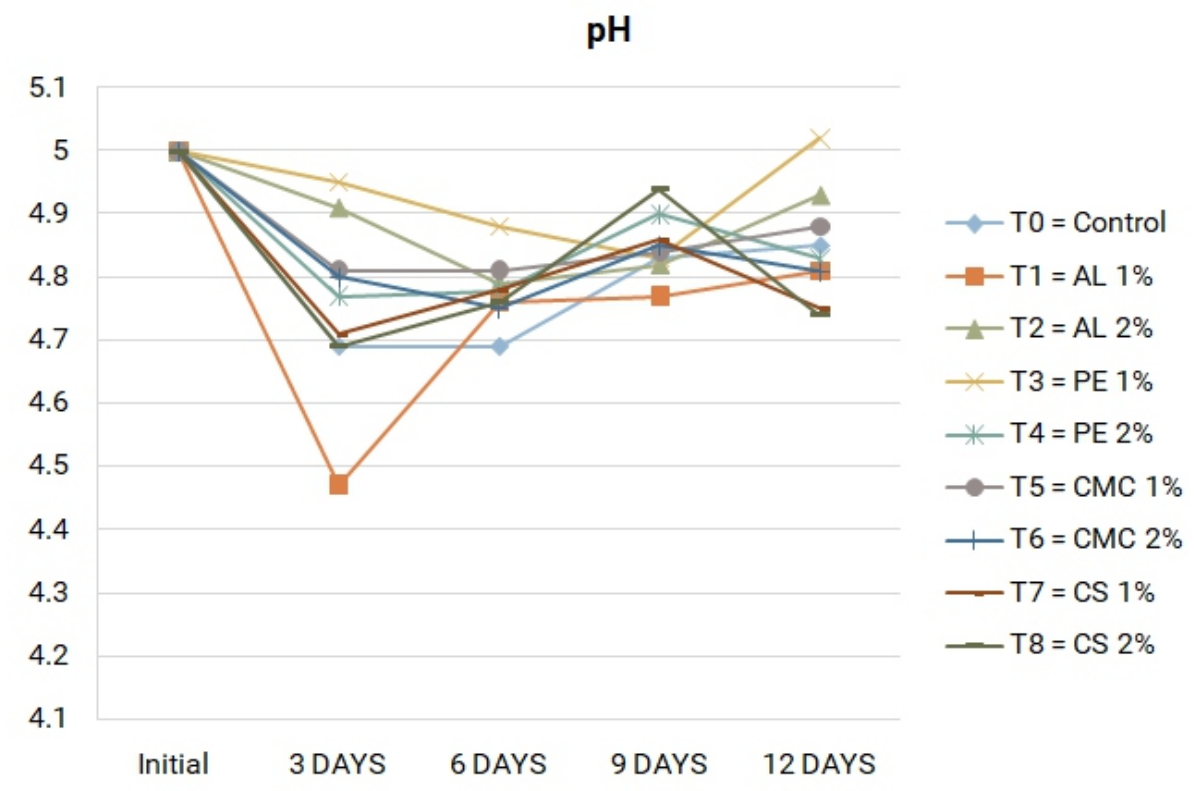

Figure 6. $\mathrm{pH}$ of eggplant fruits var. 'Morena' as influenced by different polysaccharide-based edible coatings from day 3 to day 12 .

\section{Total Soluble Solids}

Total soluble solids indicate the proportion of dissolved solids, such as sugars, acids, amino acids, ascorbic acids, and minerals in fruits and vegetables (Kader 2008; Beckles 2012). The total soluble solids among treatments increased as storage time increased (Figure 7). At harvest, the TSS was $4.78{ }^{\circ}$ Brix. In general, it seems that total soluble solid content tends to increase over the storage period as a consequence of the ripening process (Benitez et al 2013; Albanese et al 2007).

The Analysis of Variance revealed significant differences among treatments means from day 3 until day 12 . It was observed that fruits coated with edible coating had slightly lower TSS particularly CMC $2 \%$ and CS $1 \%$ (day 3 ), CMC $1 \%$ (day 6 ), PE $2 \%$, CMC 1 and $2 \%$, and CS $2 \%$ (day 9 ) compared to the control. However, on day 12 of storage, coated and uncoated fruits were comparable with each other.

In this study, there was a gradual increase in TSS during the storage period. According to Kader (2008) and Beckles (2012), the increase in the concentration of the total soluble solids in the sample is directly related to the increase in water loss during the storage period. With an increase in storage time, the starch converts into sugar in the tissues, which indicates an increase in TSS (Bourtroom 2008; Moalemiyan and Ramaswamy 2012).

Togrul and Arslan (2004) reports that TSS increased during storage conditions because of the breaking of carbohydrates and pectin, incomplete hydrolysis (breaking down the bonds due to water) of protein, and decaying of glycosides in the minute units through exchange of gases. However, it was observed in the study that the application of edible coating slightly reduced the change in TSS. Edible 


\section{Polysaccharide-Based Edible Coatings Improve Eggplant Quality}

coating delays this process as coating slows down the metabolism by reducing internal respiration rate; thus, avoiding drastic reductions of soluble solids levels (Saha et al 2016) of coated eggplant compared to the control (uncoated). This implies that changes in TSS in coated fruit was slower than in the control.

\section{Total Soluble Solids}

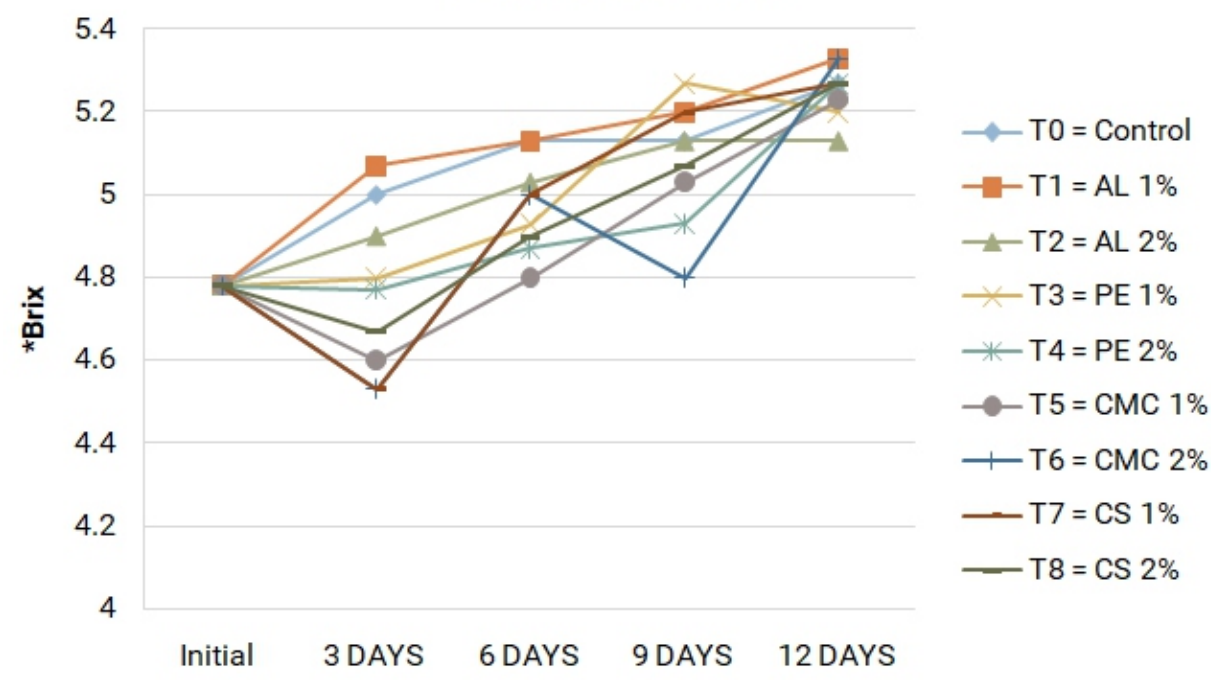

Figure 7. Total soluble solids of eggplant fruits var. 'Morena' as influenced by different polysaccharide-based edible coatings from day 3 to day 12 .

\section{Titratable Acidity}

The Analysis of Variance for the titratable acidity revealed significant differences among treatment means after 3 days of storage only and not significant at 6,9 , and 12 days of storage (Figure 8). This implies that the application of different coatings has a significant effect only within a short period of storage. Moreover, the control had the statistically highest titratable acidity. This was significantly comparable with the eggplant coated with alginate, pectin, CMC, but not comparable with eggplant coated with cornstarch.

In general, fruit acidity tends to decrease with maturation and a concomitant increase in sugar content (Raffo et al 2002). During the post-harvest storage of fleshy fruit like eggplant, reduction in total acidity is also common and is caused by the use of organic acids as substrates for respiratory metabolism in detached fruit (Díaz-Mula et al 2012; Valero and Serrano 2010). Coatings serve as a protective layer around the fruit, causing it to accumulate less acid (Díaz-Mula et al 2012; Valero and Serrano 2010)

In a similar study, the loss of vegetable acidity has been associated with decrease in quality during postharvest storage of vegetables, the retention of acidity contributed towards preserving the shelf life of cucumber (Zapata et al 2008). 


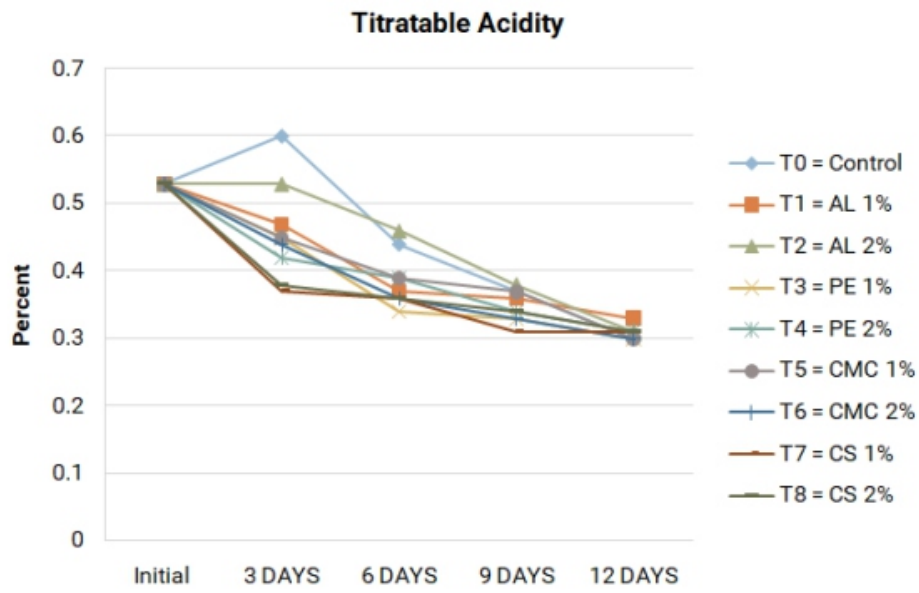

Figure 8. Titratable acidity of eggplant fruits var. 'Morena' as influenced by different polysaccharide-based edible coatings from day 3 to day 12 .

\section{Vitamin C}

Concerning ascorbic acid, it is clear from Figure 8 that it decreased with the increase in storage period, irrespective of treatments. The data also revealed that the percent decrease in ascorbic acid was significantly lower throughout the storage period in all treated fruits compared to the control. The highest percent reduction was observed in fruits without coating (control) due to high moisture loss/weight loss. Among the coated fruits, the lowest reduction was noted in alginate ( 1 and $2 \%)$, pectin, and $\mathrm{CMC}(1 \%)$.

As the moisture content decreases, the degree of dilution also decreases, according to Wang et al (2017). The retention rate of moisture content, therefore, increases and leads to lower vitamin C retention.

On the other hand, Santos and Silva (2008) and Wang et al (2017) stated that the effect of water content on vitamin $C$ degradation is more complex compared to other factors as water content brings both negative and positive effects on vitamin $\mathrm{C}$ degradation by diluting the ascorbic acid concentration, which results to a lower degradation rate.

The highest level of ascorbic acid in some treatments could be due to the retardation of the oxidation process and, consequently, slow rate of conversion of Lascorbic acid into dehydroascorbic acid by ascorbic acid oxidase. The retention of higher ascorbic acid in coated fruits might be due to the ripening retarding effect and slow rate of biological activities during storage (Hazarika et al 2017). In this study, it was noted that the possible reason for the retention of ascorbic acid in coated fruits was the reduction of the respiration rate and slowing down of ethylene production.

The result was in agreement with the study of Patrick et al (2016) who observed that some quantities of ascorbic acid (vitamin C) were lost as a result of prolonged storage. This is attributed to the fact that ascorbic acid is susceptible to oxidation by atmospheric oxygen over time (College of Science 2011). 


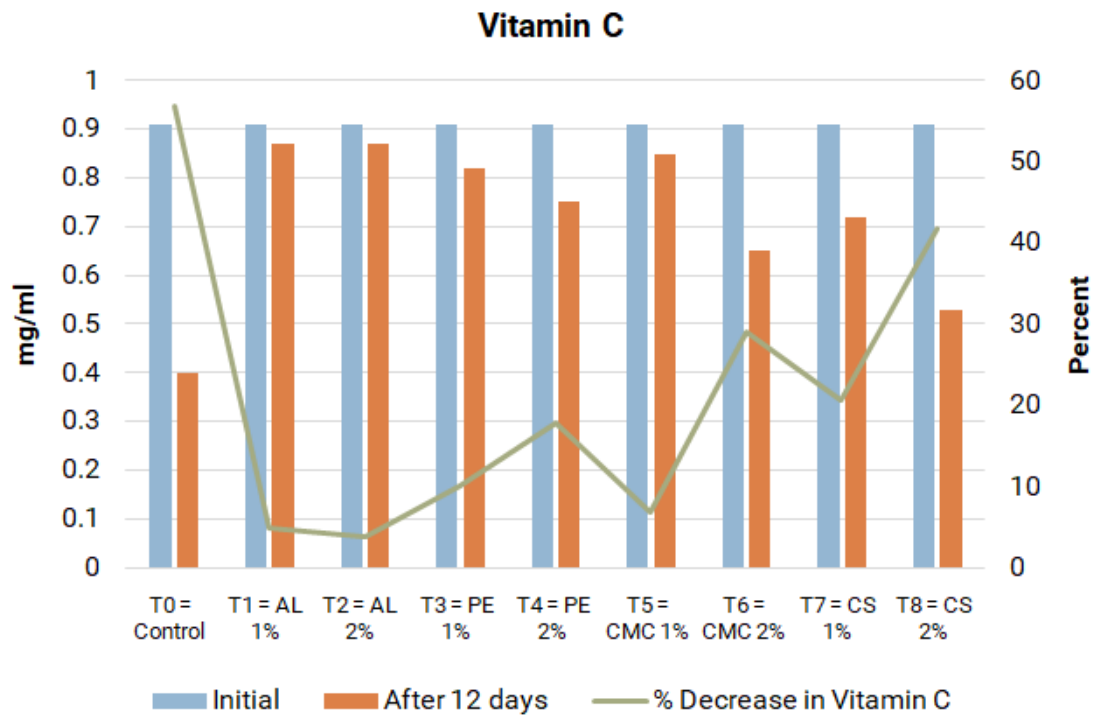

Figure 9. Vitamin $\mathrm{C}$ of eggplant fruits var. 'Morena' as influenced by different polysaccharide-based edible coatings at 12 days of storage

Coatings served as semipermeable layers which control the exchange of oxygen and carbon dioxide (Bourtroom 2008). It should be noted that ascorbic acid is susceptible to degradation by enzymes (ascorbate oxidase or peroxidase), light, oxygen, heat, and peroxides (Plaza et al 2011). Similar work was done by Bhattacharya (2004) who found that vitamin C/ascorbic acid of fresh fruits was highest before ripening and then decreased, due to the activity of an enzyme called ascorbic acid oxidase.

\section{Physiological Properties}

\section{Respiration Rate and Ethylene Production}

Respiration rate and ethylene production are important indicators of fruit quality. The lesser the respiration rate and ethylene production, the better, since the fruit can stay fresh longer if it respires and produces ethylene gradually. Results show that the respiration rate and ethylene production were lower after 3 to 12 days of storage compared to the initial, higher reading.

It was also noted in Figure 10 that respiration rate was significant at 3 to 12 days of storage. Alginate ( 1 and $2 \%$ ) showed the best result by resulting in a lesser respiration value compared to the control. Regarding ethylene production, though numerically the value was different such that the control showed the highest production, statistically the result was not significant due to the high coefficient of variance (CV\%) (Figure 11).

The barrier properties of the edible coatings also decrease the selective permeability of the fruit surface to $\mathrm{O}_{2}$ and $\mathrm{CO}_{2}$, resulting to an increase in the 
concentration of $\mathrm{CO}_{2}$ in the fruit tissues and a decrease in the concentration of $\mathrm{O}_{2}$ (de Wild et al., 2005), which may be responsible for the decreased production rate of ethylene in eggplant fruits in this study and in alginate-coated plums (Valero et al 2013).

Reduction in the respiration rate through chemical treatment, coating, and controlling the atmospheric composition could be due to the delay in the use of organic acids in the enzymatic reactions of respiration (Bico et al 2009). Coatings reduce respiratory and metabolic rates, and thereby delay the utilization of organic acids (Baraiya et al 2012).

\section{Respiration Rate}

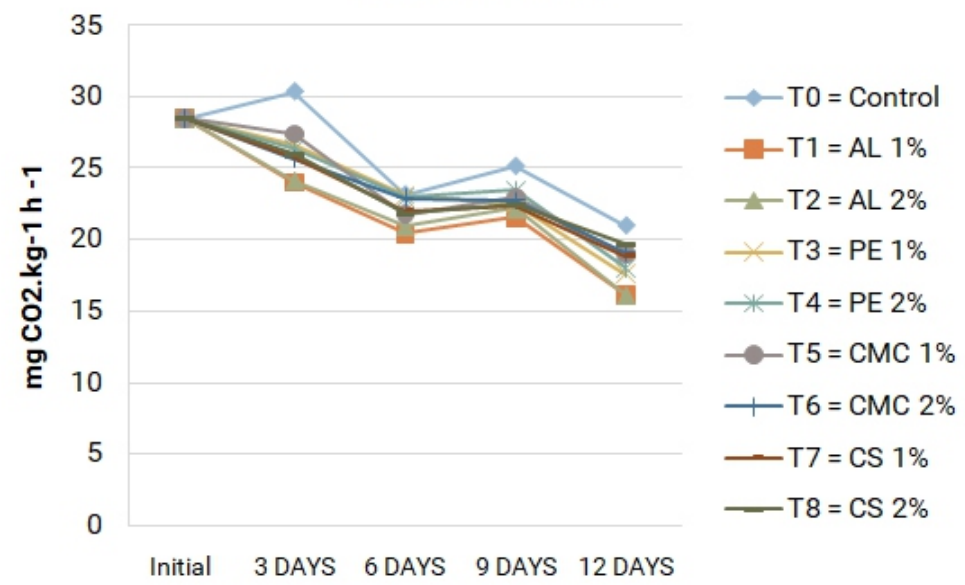

Figure 10. Respiration rate $\left(\mathrm{mg} \mathrm{CO}_{2} \cdot \mathrm{kg}^{-1} \mathrm{~h}^{-1}\right)$ of eggplant fruits var. 'Morena' as influenced by different polysaccharide-based edible coatings from day 3 to day 12 .

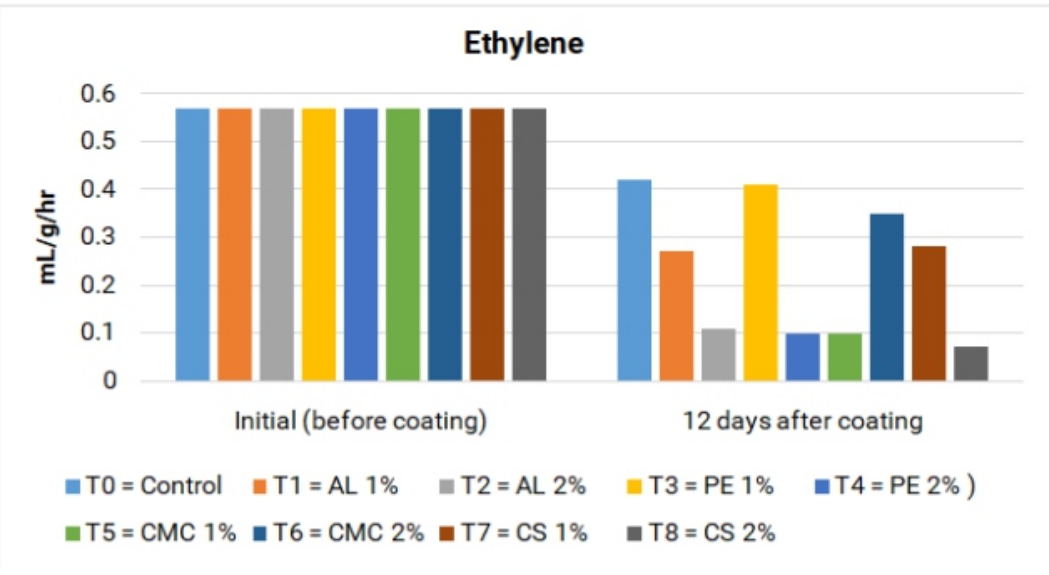

Figure 11. Ethylene production $(\mathrm{mL} / \mathrm{g} / \mathrm{hr})$ of eggplant fruits var. 'Morena' as influenced by different polysaccharide-based edible coatings from 12 days of storage. 


\section{Polysaccharide-Based Edible Coatings Improve Eggplant Quality}

Microbial Count

Statistically significant differences $(p<0.05)$ were recorded on the total microbial count. As shown in Figure 12, almost all coatings perform best in preventing microbial growth except for pectin (1 and $2 \%$ ) and cornstarch (2\%). Instead of preventing microbial growth, there was an increase in the microbial count on fruits coated with pectin (1 and $2 \%$ ) and cornstarch ( $2 \%$ ).

On the contrary, $2 \%$ alginate and $2 \%$ carboxymethyl cellulose were more effective in preventing microbial growth throughout the storage period. Fruits coated with these two had the lowest microbial count; however, these were statistically comparable to the other treatments.

It appears that fruits coated with $2 \%$ alginate and carboxylmethyl cellulose had the higher percentage of reduction in microbial count compared to fruit coated with pectin at 1 and $2 \%$ and cornstarch at $2 \%$.

The coating produces a very thin, fine layer on the fruit skin that blocks the openings of stomata and lenticels, reducing transpiration rate, respiration rate, and microbial activity (Das and Medhi 1996).

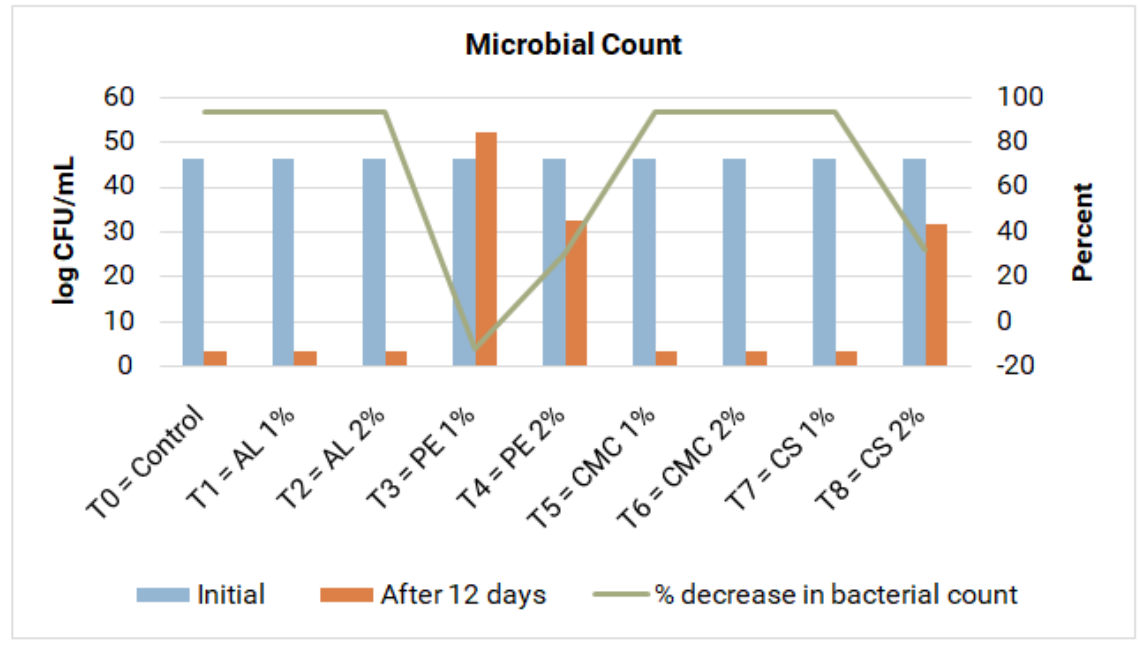

Figure 12. Microbial count of eggplant fruits var. 'Morena' as influenced by different polysaccharide-based edible coatings after 12 days of storage.

\section{CONCLUSION}

The use of different polysaccharide-based edible coatings significantly reduced weight loss and shriveling, maintained firmness and VQR, prolonged shelf life, enhanced $\mathrm{pH}, \mathrm{TSS}$, and TA, preserved vitamin $\mathrm{C}$ content, maintained moisture and dry matter content, and reduced respiration and microbial count of eggplant. When compared to the control, the different polysaccharide-based edible coatings showed the best result in maintaining the quality of eggplant especially on the percent weight loss (alginate $1 \%$ and $2 \%$ ), shriveling (alginate and cornstarch at $1 \%$ and $2 \%$ ), vitamin $\mathrm{C}$ content (alginate $1 \%$ and $2 \%$, pectin and $\mathrm{CMC}$ at $1 \%$ ), and microbial count (alginate and CMC at $2 \%$ ). The decrease in weight loss, shriveling, 
and microbial count, and retention of vitamin $\mathrm{C}$ are important in maintaining the quality and prolonging the shelf life of eggplant fruits. Among the tested polysaccharide-based edible coatings, the best was alginate at either $1 \%$ or $2 \%$.

\section{REFERENCES}

Acabal AD, Calibo CL, Loreto MTP \& Jansalin JGF. 2015. Laboratory Manual in Chem 31a: Biochemistry, Visayas State University: Philippines, pp. 48-49.

Acedo AL. 1999. Postharvest physiology of perishable crops. Laboratory Manual in Horticulture 111.Department of Horticulture, College of Agriculture, Visayas State University, Visca, Baybay, Leyte, Philippines.

Akhtar N, Abbasi A \& Hussain A. 2010. Effect of calcium chloride treatments on quality characteristics of loquat fruit during storage. Pakistan Journal of Botany, $42(1): 181-188$.

Albanese D, Cinquanta L \& Di Matteo M. 2007. Effects of an innovative dipping treatment on the cold storage of minimally processed Annurca apples. Food Chemistry, 105(3), 1054-1060.

Amanullah S, Jahangir MM, Ikram RM, Sajid M, Abbas F \& Mallano Al. 2016. Aloe vera coating efficiency on shelf life of eggplants at differential storage temperatures. Journal of Northeast Agricultural University (English Edition), 23(4), 15-25.

ASTM D2974. 2007. Standard Test Methods for Moisture, Ash, and Organic Matter of Peat and Other Organic Soils, ASTM International, West Conshohocken, PA, 2014, www.astm.org.

Ayranci $E$ and Tunc S. 2003. A method for the measurement of the oxygen permeability and the development of edible films to reduce the rate of oxidative reactions in fresh foods. Food Chem., 80: 423-431.

Baraiya NS, Gol NB \& Rao TR. 2012. Influence of polysaccharide-based edible coatings on the shelf life and nutritional quality of tomato fruit. Food, 6(1), 22-27.

Beckles DM. 2012. Factors affecting the postharvest soluble solids and sugar content of tomato (Solanum lycopersicum L.) fruit. Postharvest Biol. Technol. 63, 129-140.

Benítez S, Achaerandio I, Sepulcre F \& Pujolà M. 2013. Aloe vera based edible coatings improve the quality of minimally processed 'Hayward 'kiwi fruit. Postharvest Biology and Technology, 81, 29-36.

Ben-Yehoshua S. 1985. Individual seal-packaging of fruit and vegetables in plastic film--a new postharvest technique. HortScience 20, 32-37.

Bhattacharya G. 2004. Served fresh spotlight. Time food process. http://www.timesb2b.com/foodprocessing/dec03 jan04/spotlight.html

Bico SLS, Raposo MFJ, Morais RMSC \& Morais AMMB. 2009. Combined effects of chemical dip and/or carrageenan coating and/or controlled atmosphere on quality of fresh-cut banana. Food Control, 20(5), 508-514.

Bourtroom T. 2008. Edible films and coatings: characteristics and properties. Int Food Res J, 15(3): 237-248

Campos CA, Gerschenson LN \& Flores SK. 2011. Development of edible films and coatings with antimicrobial activity. Food and Bioprocess Technology, 4(6), 849-875. 


\section{Polysaccharide-Based Edible Coatings Improve Eggplant Quality}

Cantwell M and Suslow T. 2013. Eggplant: Recommendations for Maintaining Postharvest Quality. Department of Plant Sciences, University of C a I i f o r n i a, D a vi s, C A . http://postharvest.ucdavis.edu/pfvegetable/Eggplant/. Accessed July 2014

College of Science. 2011. Determination of Vitamin C Concentration by Titration, University of Canterbury. Retrieved 9th February 2014 from http://www.outreach.canterbury.ac.nz/chemistry/documents/vitaminc_i odine.pdf.

Das R and Medhi G. 1996. Physico-chemical changes of pineapple fruit under certain post-harvest treatments. South Indian Horticulture, 44, 5-7.

De Wild HPJ, Balk PA, Fernandes ECA \& Peppelenbos HW. 2005. The action site of carbon dioxide in relation to inhibition of ethylene production in tomato fruit. Postharvest Biology and Technology, 36, 273-280.

Debeaufort F, Quezada-Gallo JA \& Voilley A. 1998. Edible films and coatings: Tomorrow's Packaging's: A Review. Critical Reviews in Food Science, 38(4), 299-313.

Diaz-Mula HD, Serrano M \& Valero D. 2012. Alginate coatings preserve fruit quality and bioactive compounds during storage of sweet cherry fruit. Food and Bioprocess Technol., 5: 2990-2997.

Dong H, Cheng L, Tan J, Zheng K \& Jiang Y. 2004. Effect of chitosan coating on quality and shelf-life of peeled litchi vegetable. J Food Eng, 64(3): 355-358.

Gol NB and Rao TVR. 2011. Banana fruit ripening as influenced by edible coatings. International Journal of Fruit Science, 11:119-35.

Gonzalez-Aguilar GA, Celis J, Sotelo-Mundo RR, De La Rosa LA, Rodrigo-Garcia J \& Alvarez-Parrilla E. 2008. Physiological and biochemical changes of different fresh-cut mango cultivars stored at $5^{\circ} \mathrm{C}$. International Journal of Food Science and Technology, 43(1), 91-101.

Guerreiro A C, Gago CM, Faleiro ML, Miguel MG \& Antunes MD. 2015. The effect of alginate-based edible coatings enriched with essential oils constituents on Arbutus unedo L. fresh fruit storage. Postharvest Biology and Technology, 100, 226-233.

Guerreiro AC, Gago CM, Faleiro ML, Miguel MG \& Antunes MD. 2016. Edible coatings enriched with essential oils for extending the shelf-life of 'Bravo de Esmolfe'fresh-cut apples. International Journal of Food Science \& Technology, 51(1), pp.87-95.

Hazarika T, Lalthanpuii K \& Mandal D. 2017. Influence of edible coatings on physico-chemical characteristics and shelf-life of papaya (Carica papaya) fruits during ambient storage. Indian Journal of Agricultural Sciences, 87(8), 1077-1083.

Kader AA. 2008. Flavor quality of fruits and vegetables. J. Sci. Food Agric. 88, $1863-1868$.

Kaur H, Bulasara VK \& Gupta RK. 2018. Influence of pH and temperature of dipcoating solution on the properties of cellulose acetate-ceramic composite membrane for ultrafiltration. Carbohydrate polymers, 195, 613-621.

Keneko T, Claybon R \& Barringer SA. 2002. Consumer acceptability of color in processed tomato products by African-American, Latino and prototypical consumers. J Food Quality, 25: 487-498 
Kittur FS, Saroja N \& Tharanathan R. 2001. Polysaccharide-based composite coating formulations for shelf-life extension of fresh banana and mango. European Food Research and Technology, 213(4-5), 306-311.

Kowalski R, Kowralska G \& Wiercinski J. 2003. Chemical composition of fruits of three eggplant (Solanum melongena L.) cultivars. Fol. Hort. 15(2): 89-95.

Lawande KE and Chavan JK. 1998. Eggplant (Brinjal). In: Handbook of Vegetable Science and Technology, Production, Consumption, Storage and Processing. Slaunke, D.K. Kadm,S. New York. pp. 225-247.

Mancini F and McHugh TH. 2000. Fruit-alginate interactions in novel restructured products. Food/Nahrung, 44(3), 152-157.

Moalemiyah M and Ramaswamy HS. 2012. Quality retention and shelf life extension in Mediterranean cucumbers coated with a pectin-based film. Journal of Food Research, 1(3), 159.

Moreira MR, Cassani L, Martín-Belloso O \& Soliva-Fortuny R. 2015. Effects of polysaccharide-based edible coatings enriched with dietary fiber on quality attributes of fresh-cut apples. Journal of Food Science and Technology, 52(12), 7795-7805.

Nasrin TAA, Rahman MA, Hossain MA, Islam MN \& Arfin MS. 2017. Postharvest quality response of strawberries with aloe vera coating during refrigerated storage. The Journal of Horticultural Science and Biotechnology, 92(6), 598605.

Natalia VM. 2012. Development of an alginate-based antimicrobial edible coating to extend the shelf-life of fresh-cut pineapple.M.Sc. Thesis, Texas A\&M University, Texas, USA.

Nazoori F, Poraziz S, Mirdehghan SH, Esmailizadeh M \& Zamanibahramabadi E. 2020. Improving Shelf Life of Strawberry Through Application of Sodium Alginate and Ascorbic Acid Coatings. International Journal of Horticultural Science and Technology, 7(3), pp.279-293.

Olivas GI and Barbosa-Cánovas G. 2009. Edible films and coatings for fruits and vegetables. In Edible films and coatings for food applications. Springer, New York, NY. pp. 211-244.

Olivas GI, Rodriguez JJ \& Barbosa-Cánovas GV. 2003. Edible coatings composed of methylcellulose, stearic acid, and additives to preserve quality of pear wedges. Journal of Food Processing and Preservation, 27(4), 299-320.

Omus-Oliu G, Rojas-Grau MA, Gonzalez LA, Varela P, Soliva-Fortuny R, Hernando MIH, Munuera IP, Fiszman S \& Martin-Belloso O. 2010. Recent approaches using chemical treatments to preserve quality of fresh cut fruit - A review. Postharvest Biology and Technology, 57(3), 139-148.

Palou L, Valencia-Chamorro SA \& Pérez-Gago MB. 2015. Antifungal edible coatings for fresh citrus fruit: a review. Coatings, 5(4), 962-986.

Park H. J. 1999. Development of advanced edible coatings for fruits. Trends in Food Science and Technology, 10(8), 254-260.

Patrick AO, Fabian UA, Peace IC \& Fred 00. 2016. Determination of variation of vitamin ' $C$ ' content of some fruits and vegetables consumed in Ugbokolo after prolonged storage. IOSR J Environ SciToxicol Food Technol, 7:17-19

Perez-Gago MB, Gonzalez-Aguilar GA \& Olivas GI. 2010. Edible coatings for fruits and vegetables. Stewart Postharvest Rev., 6: 1-14. DOI: 10.2212/spr.2010.3.4 


\section{Polysaccharide-Based Edible Coatings Improve Eggplant Quality}

Petriccione M, Mastrobuoni F, Pasquariello MS, Zampella LE, Nobis, Capriolo G \& Scortichini M. 2015. Effect of chitosan coating on the postharvest quality and antioxidant enzyme system response of strawberry fruit during cold storage. Foods, 4(4), 501-523.

Plaza L, Crespo I, De Pascual-Teresa S, De Ancos B, Sánchez-Moreno C, Muñoz M \& Cano MP. 2011. Impact of minimal processing on orange bioactive compounds during refrigerated storage. Food Chemistry, 124(2), 646-651.

Radi M, Firouzi E, Akhavan H \& Amiri S. 2017. Effect of gelatin-based edible coatings incorporated with Aloe vera and black and green tea extracts on the shelf life of fresh-cut oranges. Journal of Food Quality, 2017

Raffo A, Leonardi C, Fogliano V, Ambrosino P, Salucci M, Gennaro L \& Quaglia G. 2002. Nutritional value of cherry tomatoes (Lycopersicon esculentum cv. Naomi F1) harvested at different ripening stages. Journal of Agricultural and Food Chemistry, 50(22), 6550-6556.

Robertson GL. 2006. Food packaging: principle and practice. 2nd ed. London, New York, Boca Raton: Taylor and Francis Group; pp. 43-54.

Robles-Sánchez RM, Rojas-Graü MA, Odriozola-Serrano I, González-Aguilar GA \& Martín-Belloso O. 2009. Effect of minimal processing on bioactive compounds and antioxidant activity of fresh-cut Kent mango (Mangifera indica L.). Postharvest Biology and Technology, 51(3), 384-390.

Robles-Sánchez RM, Rojas-Graü MA, Odriozola-Serrano I, González-Aguilar G \& Martin-Belloso O. 2013. Influence of alginate-based edible coating as carrier of anti-browning agents on bioactive compounds and antioxidant activity in fresh-cut Kent mangoes. LWT-Food Science and Technology, 50(1), 240-246.

Rodriguez S, López B \& Chaves A. 2001. Effect of different treatments on the evolution of polyamines during refrigerated storage of eggplants. J. Agric. Food Chem. 49(10): 4700-4705.

Rojas-Graü MA, Tapia MS \& Martín-Belloso O. 2008. Using polysaccharide-based edible coatings to maintain quality of fresh-cut Fuji apples. LWT-Food Science and Technology, 41(1), 139-147.

Saha A, Tyagi S, Gupta RK \& Tyagi YK. 2016. Guar gum based edible coating on cucumber (Cucumis sativus L.). European Journal of Pharmaceutical and Medical Research, 3(9), pp.558-570.

Salmieri S and Lacroix M. 2006. Physicochemical properties of alginate/ polycaprolactone-based films containing essential oils. Journal of Agricultural and Food Chemistry, 54(26), 10205-10214.

Sánchez-González L, Pastor C, Vargas M, Chiralt A, González-Martínez C \& Cháfer M. 2011. Effect of hydroxypropyl methylcellulose and chitosan coatings with and without bergamot essential oil on quality and safety of cold-stored grapes. Postharvest Biology and Technology, 60(1), 57-63.

Santos PHS and Silva MA. 2008. Retention of vitamin C in drying processes of fruits and vegetables. Drying Technology, 26(12): 1421-1437.

Sapper M and Chiralt A. 2018. Starch-based coatings for preservation of fruits and vegetables. Coatings, 8(5), 2079-6412.

Togrul $\mathrm{H}$ and Arslan N. 2004. Carboxylmethyl cellulose from sugar beet pulp cellulose as a hydrophilic polymer in coating of mandarin. J Food Eng, 62: 271-279 
Ullah A, Abbasi NA, Shafique M \&. Qureshi AA. 2017. Influence of edible coatings on biochemical fruit quality and storage life of bell pepper cv. "Yolo Wonder". Journal of Food Quality, 2017.

Valero D and Serrano M. 2010. Postharvest biology and technology for preserving fruit quality.CRC-Taylor \& Francis, Boca Raton, USA.

Valero D, Díaz-Mula HM, Zapata PJ, Guillén F, Martínez-Romero D, Castillo S \& Serrano M. 2013. Effects of alginate edible coating on preserving fruit quality in four plum cultivars during postharvest storage. Postharvest Biology and Technology, 77, 1-6.

Vargas M, Pastor C, Chiralt A, Mcclements DJ \& González-Martínez C. 2008. Recent advances in edible coatings for fresh and minimally processed fruit. Crit. Rev. Food Sci. Nutr. 48, 496-511.

Wang J, Law C Mujumdar A \& Xiao HW. 2017. The degradation mechanism and kinetics of vitamin $\mathrm{c}$ in fruits and vegetables during thermal processing.p284

Yaman $\mathrm{O}$ and Bayoindirli L. 2002.Effects of an edible coating and cold storage on shelf-life and quality of cherries. Lebnsm. -Wiss. Und. Technol., 35: 146-150.

Zapata PJ, Guillén F, Martínez-Romero D, Castillo S, Valero D \& Serrano M. 2008. Use of alginate or zein as edible coatings to delay postharvest ripening process and to maintain tomato (Solanum lycopersicon M.) quality. J Sci FoodAgric, 88: 1287-1293.

Zaro M, Keunchkarian S, Chaves A, Vicente A \& Concellón A. 2014. Changes in bioactive compounds and response to postharvest storage conditions in purple eggplants as affected by fruit developmental stage. Posharvest Biol. Technol. 96:110-117.

Zhang C, Madbouly SA \& Kessler SA. 2015. Renewable polymers prepared from vanillin and its derivatives. Macromolecular Chemistry and Physics, 216(17), pp.1816-1822.

Zhu X, Wang QM, Cao JK \& Jiang WB. 2008. Effects of chitosan coating on postharvest quality of mango (Mangifera indica L. CV. Tainong) vegetables. J Food Process Preserv, 32(5): 770-784. 